\title{
Medical topographies: Sources for the evolutionary study of territory and landscape
}

\author{
Alejandro Vallina Rodríguez ${ }^{*}$, Edith Cecilia Macedo Ruíz ${ }^{2}$, \\ Concepción Camarero Bullón ${ }^{1}$ \\ ${ }^{1}$ Autonomous University of Madrid, Spain \\ ${ }^{2}$ Panamerican University, México, Mexic
}

This research delves into the comprehensive treatment of textual geohistorical sources, promoting the procedures that currently advocate the recovery, analysis and opening of scientific knowledge in a transparent and extensive way to the society. Between the middle of the $18^{\text {th }}$ century and the middle of the $19^{\text {th }}$, some of this colonial spaces produced throughout Europe and in American, medical works (medical geographies or topographies), under the influence of the generalisation of hygienist theories in urban planning and society as a whole. These works, and their correct study and analysis, are enormously valuable collections of information and documentation for the knowledge of the urban and rural spaces of the time.

Key Words: geohistorical sources, medical geography, health, territory, medical topographies

Article Info: Received: February 3, 2020; Revised: April 21, 2020; Accepted: May 11, 2020; Online: May 23, 2020.

\section{*Corresponding author}

Address: Departamento Geografía, Facultad de Filosofía y Letras. Universidad Autónoma de Madrid C/ Francisco Tomás y Valiente, 1. CP 28049, Madrid, Spain.

Phone: + 34914974577| Email: alejandro.vallina@uam.es

(C)2020 Human Geographies; The authors

(e) $\stackrel{G}{r}$ This work is licensed under a

Creative Commons Attribution 4.0 International License. DOI:10.5719/hgeo.2020.141.2 


\section{Introduction}

Society and landscape are linked in such an intimate way and share so many aspects that a parallel analysis is almost inevitable. Both concepts are introduced as a polyhedron of natural and cultural edges, that are portrait on a dimensional space that transcends concepts such as private property limits and politicaladministrative borders, realities, ever-changing dynamics (Monna et al., 2004). The multiple meanings of the concept of landscape, attached with an impressive boom of all kind of scientific-technical, social and artistic-humanistic (Vallina, 2017a) disciplines, has provided to the field of landscaping a rich background that is approached from innumerable disciplines, with geography standing out among others. In the last three decades, historical geography has generated a heterogeneous set, on an international scale, of theoretical and methodological proposals focused on the analysis of data and societies (Taylor \& Rudwick, 2009).

The current spatial reality could not be clearly understood without paying attention to the action of human groups, the consequence of a historical reality. The image of the landscape is the result of its evolution over time, and the use of the territory also depends on the historical memory of the society that develops it. To understand the past characteristics of a certain place and society, as is the case in current studies, encourages the use of information sources that require combinations of documentation, references and data from the research action (Chun et al., 2019). In this way, the geographic discipline in many types of research about modelling and landscape analysis has been using different bibliographical, cadastral, and para-cadastral resources, cartographic materials, photographs or literary resurgences; in combination with technologies as the systems of geographical information or Big Data in many studies on modelling and spatial analysis. In recent decades numerous methods of analysis of landscape patterns have been developed and evaluated, based on these data sources, which have illuminated the concept of a geohistorical source.

Under this premise are sheltered a set of sources that contain geographical and historical data, which can be spatialised (García et al., 2018). It is not a single document or type of document, but a heterogeneous documentary group, in which a division that has traditionally been done around two prominent types: textual and cartographic sources. Regarding the technical treatment that has been applied to both groups, they have had an uneven development, in which, as a general tendency more importance has been given to image and cartographic sources than to textual ones. As to this last type of geohistorical source and the geographic field it covers, many examples can be found throughout the world (Camarero, 2002 ), such as cadastral documents and field inquiry (French terrieres, compoix y stimes, European cadasters), administrative and ecclesiastical documents, real archives, notarial acts and commercial records, all of them with their particular features, but also with an important common ground of its contents: spatialisation and territorialisation (Figure 1). 


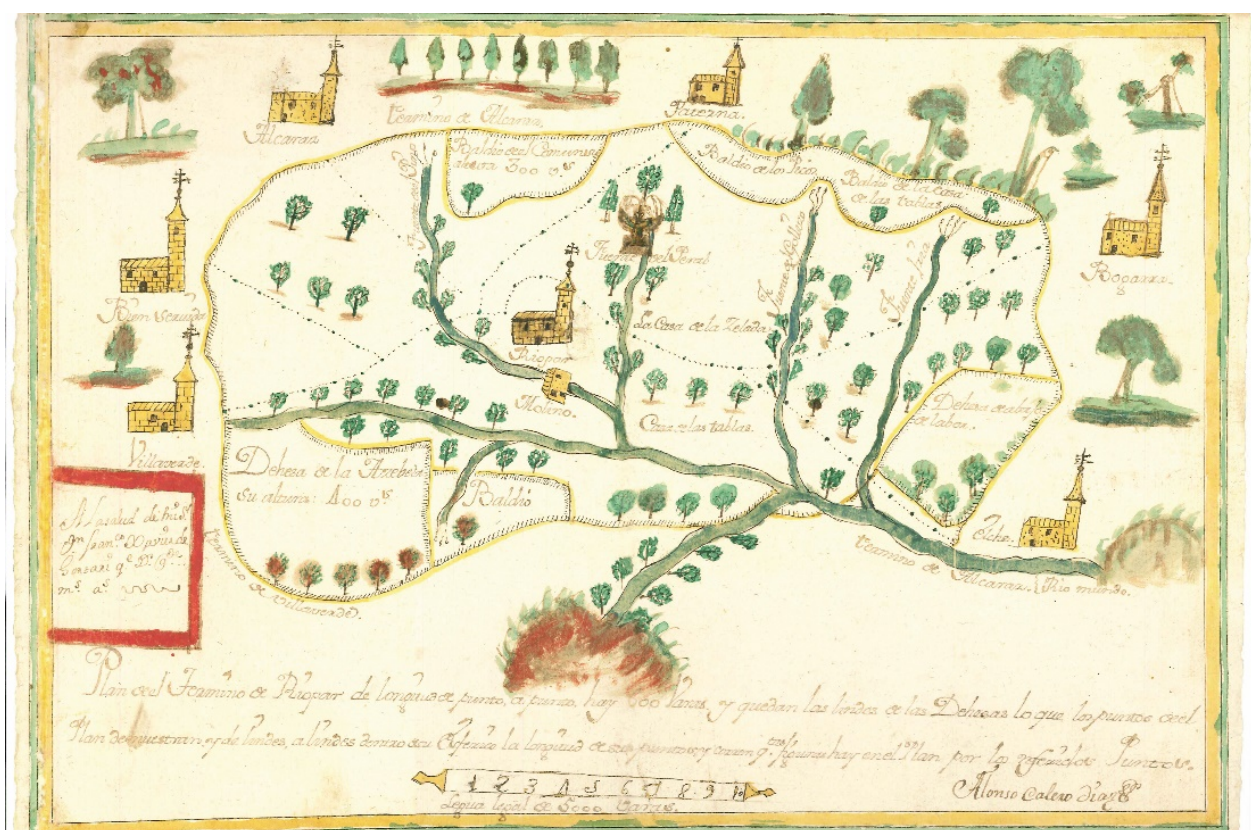

Figure 1. Ensenada cadaster map, 1752

Source: Spanish digital archive

The use of geohistorical sources as a basis for the study of the territory, especially at local and regional scales, has experienced in recent years a notable boom and continuous growth. Several congresses and seminars Have taken place in which the main focus is those written set of documents, which are becoming more and more useful because of the quantity and variety of the data they contained. The latest works, which include data analysis from geohistorical sources aim (Kwan, 2012) to work on a large variety of topics, and present the results obtained from the handling of a significant amount of information.

Without leaving this line of work, it is worth appreciating that in the last years, the research works have chosen to focus on the features of the source materials, methodology and tools used to research the information collected (Henriques et al., 2011). In other words, the understanding of sources and endorsing the information and comprehension of the social-economical and territorial framework where it has developed. In any case, the success of any investigation with geohistorical sources lies in how the whole methodology integration is done, namely the fact that it takes place when incorporating different techniques of the paleobotanical type (natural science) and documentary (social science) used during each of the analysis stages. The main challenge when using documental records as source material of any kind lies on the variety of time scales; for documentary sources, if they exist for the chosen field of study, the more one goes back in time, the more the source loses accuracy but gains value (Pèlachs, 2006). Researches based on documentary sources is understood in a broad sense, in other words, includes any kind of data source that can be recovered in any time and place. These materials may include documents of any kind, public and private, release or unreleased (archive banks), either printed or magnetic media. 
This research focuses on analysing a specific documentary source, medical topography records, also known as medical/health geography, the resource that constitutes the main textual bibliographic contribution comes from rural medicine records from Spain between the $18^{\text {th }}$ and $20^{\text {th }}$ centuries (Urteaga, 1980).

This is a comprehensive source of paramount importance for the geographical and historical disciplines, since it provides technical data and captures the line of medical thought on the last years of $18^{\text {th }}$ century Europe, characterised by focusing on the environmental and social aspects from local (and rural) areas, in the processes that affect the health of people and communities. Therefore, it is the clear exponent (Figure 2) of the medical and socio-cultural mindset of the time, as well as an excellent source of information on the types and strength of morbidity and mortality on the moment for the different spaces (Meade, 2014).

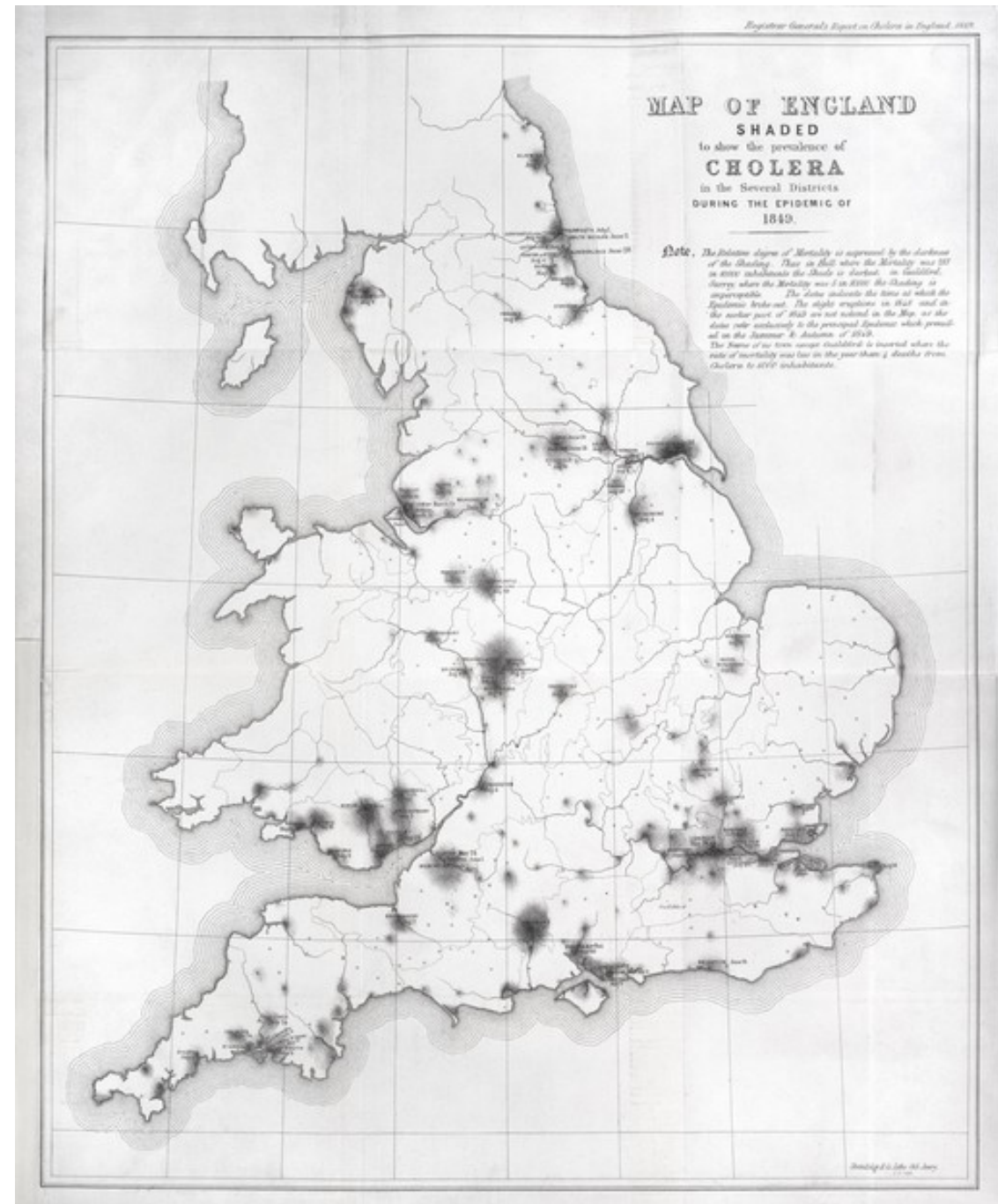

Figure 2. Map of England showing prevalence of cholera, 1849 Source: Europeana collections 
For this reason, its interest lies in the information that contains, not only on health aspects but also in the relationship between them and the physical, biological, historical, social, territorial or demographic issues of geographical frameworks to which they refer. The high levels of completeness embodied on medical topographies allow us to analyse the agricultural abandonment processes on marginal areas and crop intensification in more productive areas, homogenisation and densification of forest formations or urbanisation and wide dispersed infrastructures along with rural areas, in the particular case of Spain. While is true that some of these landscape elements can be known through other textual and cartographic geohistorical sources, the topographical analysis provides systematic and cross-sectional data on aspects rarely treated, as well as certain aspects less known in historiography and recent geography, which can help answer questions, such as when and how has the change in the perception of rural spaces been produced by the population? What relevance has the rural world had in the hygienist theses of the last century? How does the evolution of the landscape interact and how to take advantage and inhabit the human being?

In the case of Spain it is necessary to have a reliable data source for the whole territory, which can be extrapolated. Medical topographies have allowed the development of this goal, proving that the society-territory-health relationship has not followed a linear evolution in space or time. In this sense, historical geography (Cardenas et al., 2019) has allowed the reconstruction of a set of characteristics and components of the territory, that are valuable for society in the regions of the interior of Spain since the end of the $18^{\text {th }}$ century, revealing social and spatial key aspects of that time. The regular consultation of these sources (which in this paper shows the geographically based aspects of the document prepared by Dr. Hernández Briz (1909) Geography or medical topography of the Guadarrama Range Municipal Party of San Lorenzo), has provided access to the singularities that, always focusing on the perspective of human geography, identify territories that have socio-sanitary potential in the mountain region of the inner Iberian Peninsula since the end of the $18^{\text {th }}$ century. It also helped characterise traditional hygienist practices in the rural environment at a local scale and analyse the evolution of spatio-temporal patterns in the establishment of physician offices, clinics, hospital and other healthcare facilities all over the Iberian Peninsula. This is, therefore, the most relevant contribution of this research, by synthesising the frame of a methodology that can be extrapolated to other territories, which would allow a complete analysis of rural Spain during an almost unknown period and the creation of an original database that could be incorporated and adapted to environments with similar cases.

\section{Medical topographies as a basis for analysis}

As indicated, the origins of medicals topographies must be framed not only from the Iberian perspective, since this kind of documents has its roots in the Enlightenment, that represents a renascence of knowledge and an explosion on 
science in Europe in the middle of $18^{\text {th }}$ century. This scientific, cultural and social movement was preceded (Ortega, 2019) by a time of the progress of rational knowledge and improvement of the techniques of science, all enhanced by a thriving bourgeoisie guided, among others, by the precepts of rationalism, utilitarianism, idealism and naturalism. Some of these ideas are the frame to comprehend the substantial change in attitude towards nature, and more specifically, to mountain landscapes, which took place on the enlighted Spanish society. However, this happened later than in the rest of the surrounding countries, who also experienced an in-depth process of transformation in the cultural and humanistic sphere. The emergence of this renovation has a lot to do with the political changes that took place in Spain after the Revolutionary Sexennial, from 1869 to 1874, during which the Hispanic cultural elite began to develop, with university professors and researchers of the time as the head of the movement, a change of mentality took place, undoubtedly linked to cultural and political movements born in Europe. These professionals and thinkers from many different disciplines of knowledge came into contact with European movements during the travels abroad.

Thus, one of the disciplines that was influenced the most by these great Spanish science transformations was medicine, because of the need to improve society's health care, as it suffered from high morbidity and mortality rates in large layers of the population as a result of virulence of diseases and outbreaks. These had a high incidence (especially "morbo's cholera") as a result of the lack of hygienic practices in highly populated areas, cyclical in some cases and chronic in many others, malnutrition, as a result of the crops randomness which were dependent on climate conditions, and especially, overcrowding in fast-developing cities lacking infrastructure. Within the novel trends of the medical avant-garde were the hygienist conceptions, which influenced the importance of the environment on the quality of life, the ones that have the greatest importance in the first moment in society. Experts and scholars of the time used many ways and platforms used by to criticise the absence of health conditions in industrialised cities, as well as the living and working conditions of factory workers. However, one of the most successful expressions, due to the temporal and spatial importance of their postulates, were medical topographies, understood as:

"The study of specific geographical locations and their population, which is approached from a hygienic-sanitary perspective and that comprise, as a general rule, description of fiscal place (location, weather, soil, hydrography) and the biological environment (plants and animals); historical background, the physical temperament and moral character of its inhabitants, customs, life conditions, demographic movements, dominant pathologies among the population and disease distribution, All of this addressed with the purpose to promote measures to prevent them, treatments and improve health of the people." (Casco 2001, p. 217)

This will be the documentary model for medical topographies, which was only used in Spain to compose a descriptive corpus of approximately 400 municipalities and regions - taking place in the last five years of the $19^{\text {th }}$ century 
which was the moment of its maximum expression. Medical topographies usually open with a historical review of the city, a study of the physical geography of the place, including topography, climate, descriptions of plants and animals, and an economic-social overview, including agricultural production, general economic situation, communication routes, as well as a description of inhabitants' "temperament", an overview of urban hygiene and description of the streets, public and private buildings, a section about demography and finally a report of most common disease.

The Enlightenment that took place in medicine was led by the development of descriptive-deductive models in most of the western and colonial world during $19^{\text {th }}$ and $20^{\text {th }}$ centuries. This has had a clear influence on the documentary set analysed in this research. It is important to highlight that medical topographies, in particular those that made in the Spain of that time, benefit directly from this influence focused on three specific points (López, 1992), which very relevant for the disciplines of Social Sciences in general, and geography in special. In one hand these are documents that give great importance to the environment and space, despite originating from the field of medicine, they do not hesitate to place the physical environment as a decisive factor of acute diseases, especially in outbreaks and seasonal illnesses.

Secondly, the ideas portrait in medical topographies are given by the countless amount of technical and scientific advancements in the field of medicine in the fight against epidemic diseases. In these writings, doctors put in the service of society advances in the field of medicine, proposing concrete adaptations based on the physical and human factors of the spaces analysed. Thirdly, medical topographies nourish from considerations and contributions to society of socalled therapeutic naturalism (Kearns \& Joseph, 1993). The appreciation of nature by the Enlightenment also owes much of its subsequent generalisation to the upper layers of the European social sphere to the Romantic current, and in the specific case of medicine, it would lead to the valuation of nature and away from big cities, such as coastal and mountain areas, seen as healthy places for humans.

\section{The Guadarrama range and scientific progress in Spain in the $19^{\text {th }}$ and $20^{\text {th }}$ centuries}

This documentary source thus becomes the necessary point of convergence, at the time, between the discovery of Earth's physical characteristics and the behaviour of the human body and diseases. This positions medical topographies at the forefront of knowledge of the social and environmental aspects of human diseases (working conditions, food, housing) and their treatment. The importance of Guadarrama range on the context of the scientific renewal current and a remarkable combination of natural characteristics, combined with a mountainous environment, since it corresponds to most of the east half of the Central System, a mountain range located in the inner part of the Iberian Peninsula. Precisely the location of this enclave, located between Madrid and Segovia provinces, immediately fixes the attention of modern landscaping and geographical 
movement. Interest was also greatly increased by the studies that the most renowned geologists of the last quarter of the $19^{\text {th }}$ century performed in this area, producing an updated image and a scientific explanation for the geological origin of the Iberian Peninsula.

The Guadarrama Range was "discovered" (Ortega, 2019) as a scientific object within the framework of a flourishing Naturalism in Spain during the last years of $19^{\text {th }}$ century and beginnings of the $20^{\text {th }}$. Guadarrama mountains, due to its proximity to the capital Madrid, became one of the scientific and cultural spotlight of the time, with many of the aspirations of the movements of this period, such as beneficial contact with nature, the integral education in freedom, the progress of the country or the incorporation of the Spanish science into the European one, being projected on them.

In this context, Baltasar Hernandez Briz writes la Geografia o Topografía medica de la Sierra del Guadarrama: Partido Municipal de San Lorenzo, the work that is included in a 1904 project of the Royal National Academy of Medicine planned to perform a medical topography for every Spanish municipality, with more than 8,000 inhabitants. This enterprise of enormous proportions has the purpose of conducting a global analysis of the topography as an etiological element in the evolution of infectious diseases, similar to other international projects (Parr, 2004), to deepen the analysis of the natural and social determinants of diseases. The work on the Guadarrama Range is framed on the early stages of the plan that will take place from 1885 to 1933 , a neat stage of the project, where analysis of more than hundred Spanish municipalities (Casco, 2001) are performed, among them, a score of the province of Madrid (Figure 3).

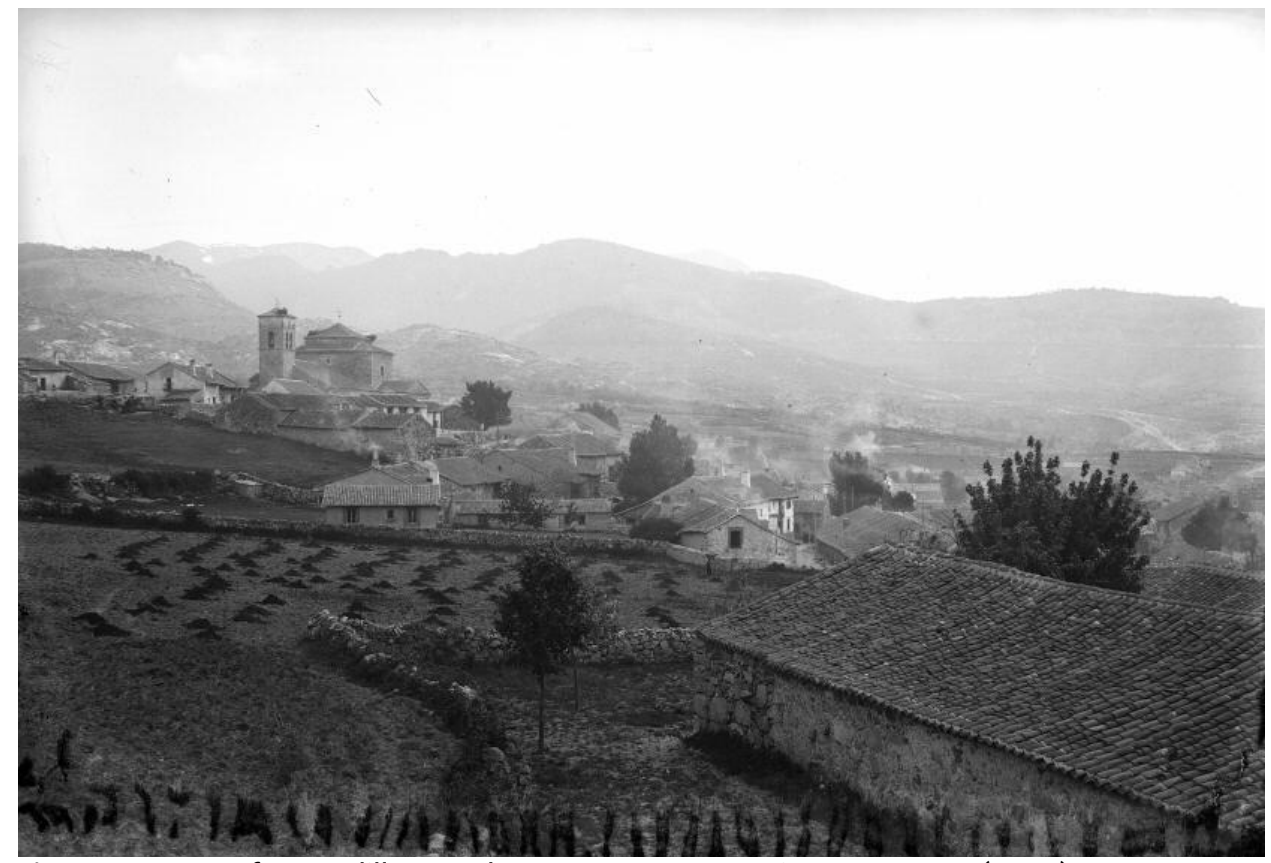

Figure 3. Town of Cercedilla. Guadarrama range. Antonio Passaporte (1927)

Source: Cultural Heritage Institute of Spain 


\section{Results and discussions}

From the geographic perspective, the approach to the Guadarrama Range is behind the current understanding of Spain's mountain landscape (Vallina, $2017 \mathrm{~b})$. The educational background of the physicians involved in the making of the medical topography in the whole of the natural sciences, as well as its firm determination to inform the population about the rich and diverse natural spaces of Spain through their fieldwork and scientific dissertations, favoured the idea of nature as a single entity, generated from the association of its elements. The Guadarrama range turned into the focus of constant admiration of the Spanish research elites to be considered the most remarkable exponent of the tectonic and lithological configuration of the Iberian Peninsula, with the enclaves of the Lozoya Valley and Peñalara as places of particular importance, in short, as an evidence of the most remote geological past of almost unspoiled peninsular territory due to the stability of its composition. Next, this mountain range, also known as the Carpeto-Vetonic Mountain Range, was considered (Ortega, 2019) the true backbone of the peninsula, and was inextricably associated with the Castilian Plateau as its primeval nucleus. The variations and pressures applied to these spaces gave them an image not known before from 1910s (Figure 4), when the tensions generated by the advance and expansion of new urbanised spaces helped by the improvement of communications between mountain spaces and large population centres caused a progressive loss of rural landscapes. These latter spaces witnessed a great diminished on their traditional functions, adapting to cover the growing housing and leisure demand of Madrid citizens inside cities.

As a result of this set of factors, The Guadarrama range was begging to be seen, since 1860, as a beautiful place, full of natural resources that urban spaces lacked, and therefore, a beneficial territory for humans, where nature can be appreciated in its purest state, where one can maintain or recover their good health. This would lead a progressive establishment of healthcare facilities. The process is consistent with the general fact that the idea (Labasse, 1982) of the development of healthcare facilities on mountain environments was born from these premises, as places with exceptional qualities for mental and body healing, which targeted the increasingly overcrowded populations on unhealthy cities.

As told before, an important fact for the valuation of the space studied here is its proximity of state capital, a city that had a fast and continues growth during the second half of $16^{\text {th }}$ century, which had a negative consequence for its environment. The idea of space as something physical, which could stimulate healing, had dominated the imagination of different societies since ancient times, although there has been a more or less almost steady balance between perceiving space as a threatening environment or considering man as another component of territory. This statement is grounded on the fact that a change of environment what is understand nowadays as "health truism" - has been practised over the centuries by numerous civilisations, from Mesopotamia to the present day. Nevertheless, healthy spaces have traditionally revalued the perception about territories, and the Guadarraman area is a good example of this dating back to 
the $19^{\text {th }}$ century. With the arrival of the Enlighten ideas in Spain's cultural and scientific life, came this vision of the Guadarrama range in the scholarly circles of the first quarter of the $19^{\text {th }}$ century. Blas Llanos, a member of Royal College of Physicians of Madrid, published in 1825 the Report on the Means of Improving the Climate of Madrid, Restoring its Health and Fertility (English translation) (Llanos, 1825), in which, in addition to offering a general idea about the Madrid's population and its soil and natural environment, the writer offers a point of view about the reality that made that village valuable to Felipe II and made him set his Court headquarters here and no other Hispanic cities.

\begin{tabular}{|c|c|c|}
\hline กับ์ 291. & \multicolumn{2}{|l|}{ MADRID 27 DE JUNIO DE 1861.} \\
\hline \multicolumn{3}{|c|}{ 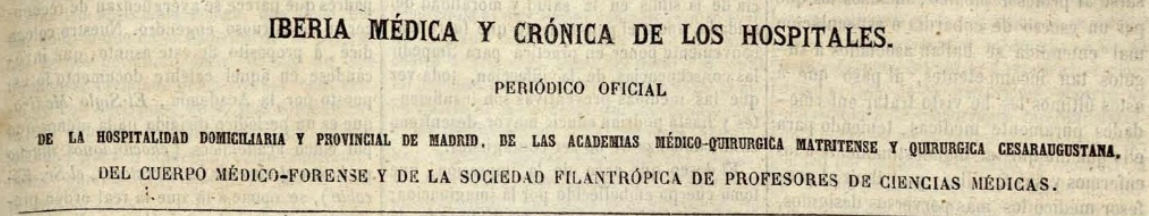 } \\
\hline 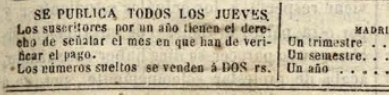 & 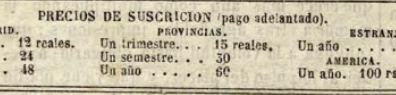 & 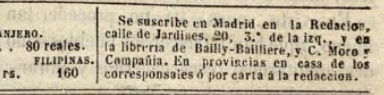 \\
\hline 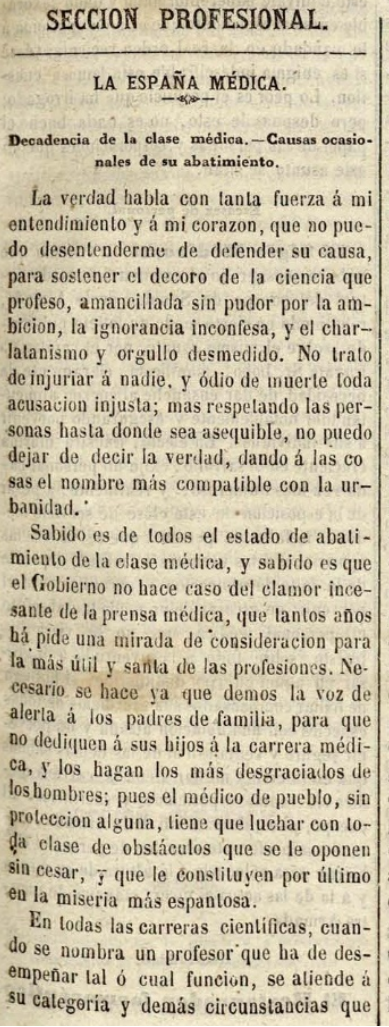 & 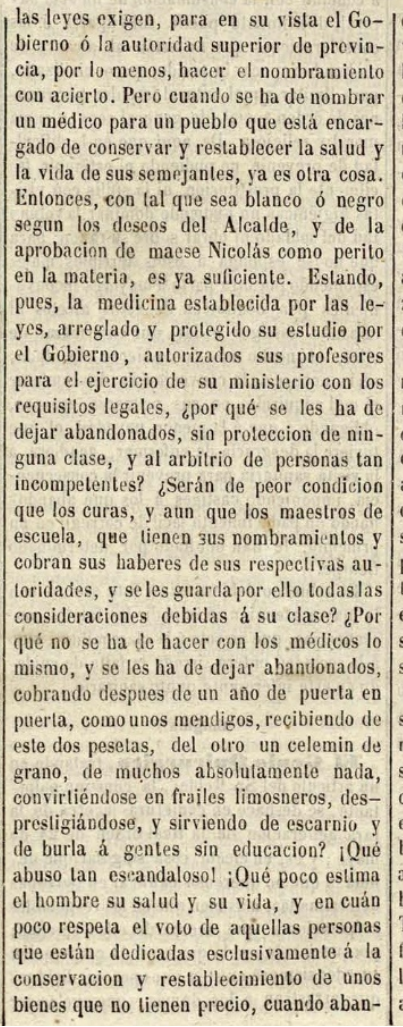 & 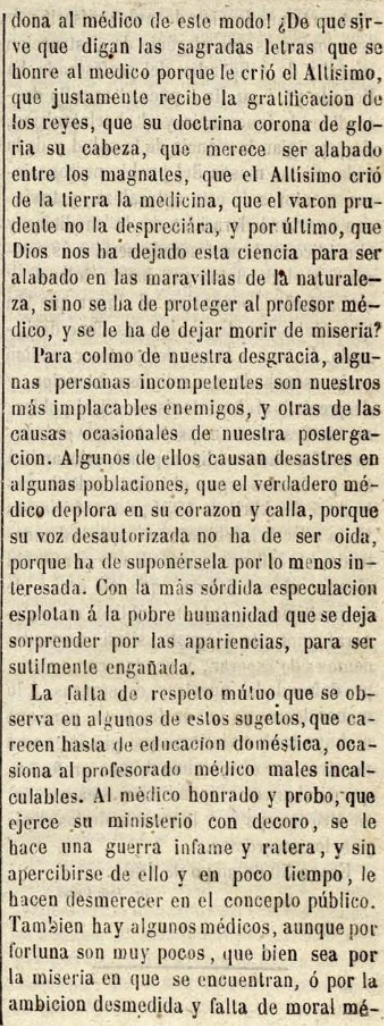 \\
\hline
\end{tabular}

Figure 4. Extract of a newsletter medical disclosure 1861

Source: Library of the Royal medical Society of Spain 
The paper includes information on how men began to alter the natural conditions of the growing city and its surroundings, substantially worsen the living conditions of its inhabitants. Clear references to the Guadarrama range can be found inside this paper, with important natural characteristics being attributed to them, but portraited as a remote and inaccessible place, far from the city. The European Romantic current came to change precisely this view starting in 1860, without a doubt due to an improvement of the communications routes since previews centuries, specifically the opening of Leon's road and the harbour, the continuous improvement and maintenance of roads that, from Madrid, that leads to The Royal Palace of la Granja de San Ildefonso. "To the North is Madrid, the highlands and mountains of Guadarrama, made of big cliffs, forest, trees, scrubs, ominous valleys, rainbows and unreachable tops" (Llanos, 1825, p. 37).

The writer emphasises, with a somewhat idealised view, that before the Court of Madrid was moved in 1561, this enclave and its surroundings were of great value and its inhabitants enjoyed a benevolent climate. It was the renovating decisions of King Felipe II that led to an exponential and disorderly growth of the population of Madrid. The author considers that the beginning of the degradation of the nature of Madrid came about During this time of demographic expansion, linked to the settlement of several noble houses, convents and state administrative buildings. To Llanos (1825), the logging of the city surrounding woodland to supply the population with coal and firewood, the drying of every well and water spring during that age in Madrid, was the reason behind the loss of the natural environment and health of territory. It was only during the reign of Carlos III that Madrid sees an improvement in health and hygienic conditions since during these years a sewerage and garbage recollection system was implemented, street cleaning and rehabilitation of urban landscape was done materialised through the creation of vast outdoors public green spaces or the channelling of the Manzanares River and projects of tree planting of its banks. Two essential measures (Campos, 2008) for the maintenance of health conditions in the Spanish capital and the improvement of the living conditions of its inhabitants are cited: the surrounding woodlands and large areas surrounding the city, and the supply of water to cities by viajes de agua and some water canals coming from the Jarama river. It is very important to know that the viajes de agua systems or qanats exist in cities since Hispanomuslim times (Figure 5).

In the work Geografia o Topografia Medica de la Sierra de Guadarrama (Partido Municipal de San Lorenzo), Hernández Briz (1909), express opinion of public health professionals about the benefits and natural characteristics that made the Guadarrama range the perfect place to cure particular diseases that were the scourge of populations of that time, especially that of the nearby Villa and Corte.

\footnotetext{
"From the analysis we have done of all the elements that integrate and specialise this mountain climate of this region, it is seen that Nature has placed a wonderful natural sanctuary of the first order in our hands, as perhaps there is no other that matches it." (Hernández Briz, 1909, p. 24)
} 


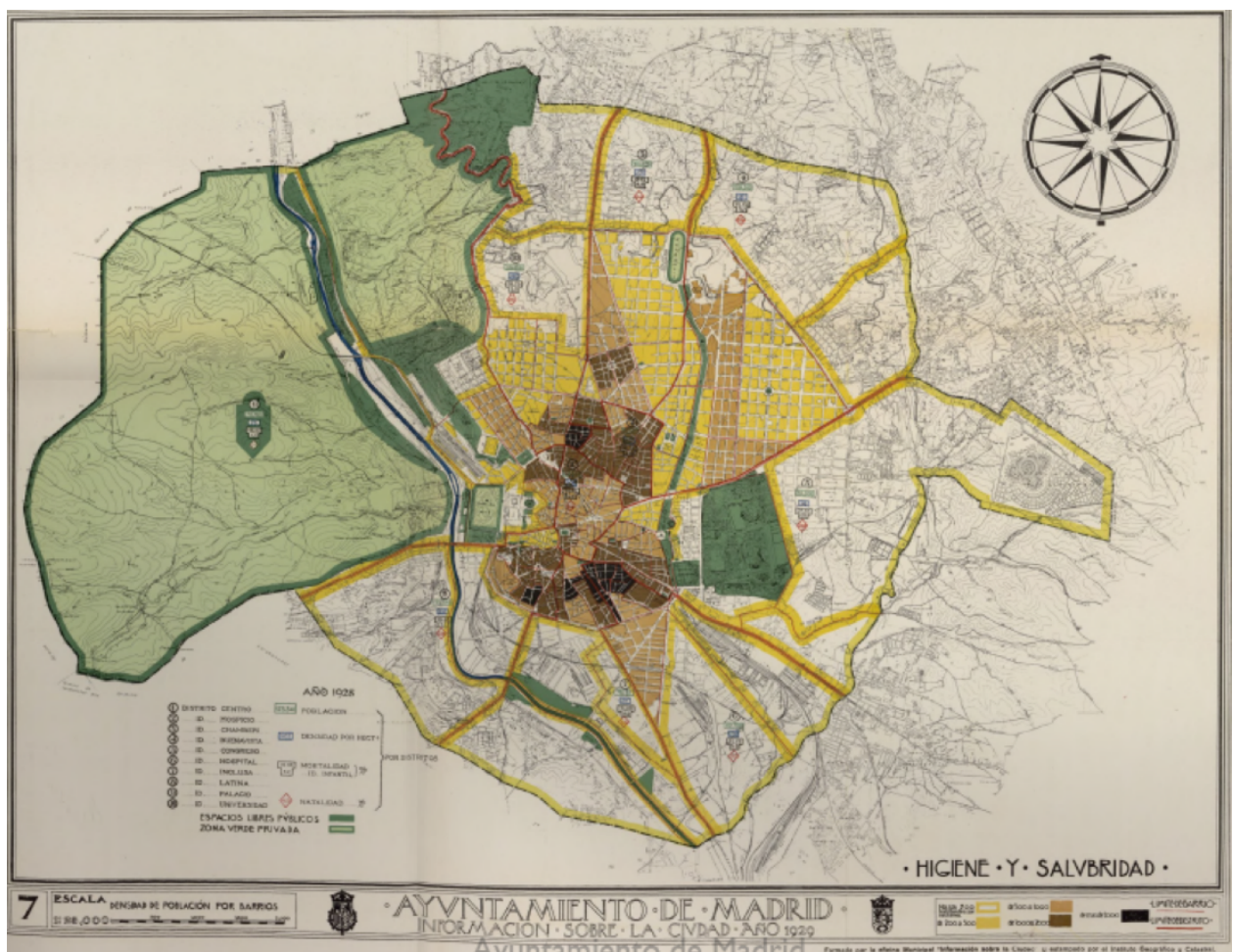

Figure 5. Information on the health of Madrid 1929

Source: City found of Madrid

In addition, all the listed beneficial conditions for humans being quoted in this document are supported by the writer's practical knowledge as a doctor:

"Behold the children raised in the mountain, outdoors, bathed by the sun and oxygen, tanned by their surroundings, if these children have an hygienic living place, they will be sturdy and strong[...]; make a comparation with those children of the same age, raised in the narrow streets of big populated areas, without taking any sun light and without enough air to breath[...], and you will see that these are withered, anemic and sickly beings." (Hernández Briz, 1909, p. 27)

Hernández Briz and other colleagues of that time dedicated a good part of their research and works to state that this regions of Guadarrama was the natural lung of Madrid where those with weakened organisms can find regeneration. In this context, it should be noted that the idea this paperwork is based on is that of a Guadarrama Range as a mountain range, dominated by regular slopes and welldefined valleys, with the Lozoya trench or valley as the predominant internal valley between large high masses and of a capital importance in the natural and human development of this limited mountain space. On the relationship between lithological composition and the dominant soil of this area of the Central System and its connection with the view of scholars at the beginnings of the $20^{\text {th }}$ century and health benefits on the population Dr. Hernández Briz also states: "Granite and gneis make an impermeable soil, this quality it's very important, as we know 
that populations that settle in this kind of ground, own great immunity to waterborne diseases" (Hernández Briz, 1909, p. 57).

The same author points out that impermeable qualities, and mineralisation of the predominant materials in the Guadarrama range results in an environment without a match for surface streams and underground water, giving birth to numerous water sources, with unmatched hygienic conditions due to their origin from melting of snow and natural filtration to which they are subjected by the action of the granite and gneiss itself. In the same chapter of the work previously cited, it is mentioned almost anecdotally, that some minerals present in the region, especially granite have a radioactive. From a purely medical point of view, this work on Geography or Medical Topography about the Guadarrama range recommends this climate especially during the convalescence of infectious diseases and age-related illnesses, with special emphasis on health care that the authorities should show to children.

"The sea climate has beautiful indications [...], but it has great contraindications. The climate of Guadarrama range, at the average height that can be used, has no contraindication and is called to provide great services to humanity, when its admirable conditions are vulgarised." (Hernández Briz, 1909, p. 64)

For this reason, Hernandez Briz and the physicians who practised the profession in these mountain enclaves investigate the symptomatic tendencies of the population that dwell in those areas defending the generalisation of preventive healing stays for risk groups, as these lines demonstrate:

"In this place the preventoriums must be located, in Guadarrama and los Molinos valley. This is a suitable place for them. Mayoralties and Deputations must build simple pavilions for the children to spend Summer and Fall season in this place [...]. Also, beautiful outdoor forest houses could also be built." (Hernández Briz, 1909, p. 69).

And this work ends with a very remarkable phrase about hygienic conditions that scholars of that time attributed to the Guadarrama mountains environment, that, will stand behind the further construction of the Health Centers.

"In the present study we have proposed to make known to doctors and general public, the remarkable conditions of this first-class health center facility to be use in benefit of humankind, since Nature has put at the doors of Madrid this incomparable region" (Hernández Briz, 1909, p. 75).

In other works of his about Mountain Health Care Facilities for Tuberculosis Hernandez Briz (1919) takes one step further in the quest for an effective treatment for tuberculosis, a real problem for doctors of the time. At a time when the disease spread throughout urban environments all over Europe, the doctors and clinicians from la Royal Academy of Medicine of Spain wanted to demonstrate that mountain climate from the peninsula's centre and the Castilian plains were the places where people suffering from this very contagious disease could find pure, invigorating and stimulating air that will bring them healing. To illustrate this 
idea, the author himself appeals to his accredited experience for more than three decades to point out that, in areas such as Guadarrama's mountain range, Gredos and Valle del Tiétar, those diseases were almost unknown. Hernandez Briz bases this fact on the natural conditions of these zones that make them prophylactic spaces for this condition. The dry climate of high mountains of central Peninsula area, geology dominated for primitive materials that release radiation, a clear sky during most of the year, heights about 1,000 and 2000 meters above sea level, the predominance of a rich and substantial diet, the possibility to find perfectly drinkable water springs, and vegetation that produces a scented and fragrant scent behind of it, made this as the ideal place for the treatment of tuberculosis and other respiratory or nervous related diseases. As such, he stated that efforts to see an improvement in urban public health should materialise with great investments in modern equipment outside them.

The author closes his brief essay with a series of conclusions related to health care facilities for tuberculosis, which constitute the scientific justification of the construction projects of health care facilities and clinical care centres in the Guadarrama range and other points of similar characteristics throughout Spain.

1. Mountains health care facilities must multiply in the country, so to better treat tuberculosis.

2. Studies about climate conditions must be given priority when searching for a sanitary station; in other words, it must be ensured that a place gathers the natural characteristics for the healing of tuberculosis and many other diseases that afflicts man.

3. The construction of various pavilions or houses in an ample space (sanitary station) [...] must be located near a town.

4. The construction of a building called sanatorium for workers and homeless people $[\ldots]$ it will be very useful and necessary for them to multiply in the country, and due to the rugged territory there will be ideal places where they can be installed.

About the topographic conditions of Madrid as a source of infection, it is proposed to transfer land from the state surrounding the municipality of Madrid and to repopulate them with trees, mainly pine and other conifers. Likewise, it is proposed as a solution to enlarge the municipal district of Madrid so as to disperse the activities it hosts in its jurisdiction. In this regard, palliative measures such as drying stagnant water or the commitment of proper exploitation of forest areas are also included in the text. For all this, it is necessary to venture out, and in the next years, health care centres, health and civil authorities of that time found in Spanish mountain spaces a haven of nature and rest, which due to their climate and biogeographic characteristics, were seen as a place to settle health care facilities capable of supplying the ever-growing demand of more and more crowded populated areas and with increasing greater health problems. In this context, Guadarrama becomes a place extolled by Romanticism and focus of the brightest nature in the nearest environment of Madrid. Doctors of that time argued that the Guadarrama range was a space of excellent health that leaves no room for any interpretation: 
"The scent that spontaneously emanates from the flora, it's also very important from the medical point of view, as is rich in aromatic and resinous species, as this happens in this zone, $[\ldots]$ as a result the dry, balmy, stimulating, scented, extremely comforting air, that, at the same time that it produces an ineffable pleasure when breathing, has true characters of being an antiseptic air". (Hernández Briz, 1909, p. 54).

It is necessary to specify the importance of the historical context that prevails in the configuration and construction of new renovating ideas in the science of the Enlightenment on a global scale. It is very interesting to understand how renovating ideas in urban planning and public health are interpreted in nonurban settings. The documentary source analysed is the response of the scientific world to the problems of unhealthiness in populated areas, the absence of prophylactic measures and minimal living conditions in the rural world. We must recognise the enormous effort that rural doctors made to interpret the information coming from the cities, with pressing dynamics of overcrowding, poverty, lack of food, growth of contamination and precariousness of the working class, and adopt the characteristics of the reality of the rural world, where the social, economic and welfare problems of the population were diametrically different.

In this sense, medical geographies and topographies must be considered as one more assertion of the classic tests of human geography, very concerned in its initial stages as a science in the consolidation of the patterns that were able to establish and explain the relationship of the geographical space with the nearness or distance of the cities. Medical topographies and geographies, as technical documents that have the purpose of relating the physical characteristics of the place, the uses and customs of its inhabitants and their medical situation, have a remarkable value in understanding symptoms and medical-sanitary aspects of to the population, but also acquires a referential value in the study of the change in the mentality about the environment, which has continued to be a key aspect in shaping the framework in which human geography has been built.

\section{Conclusions}

The medical geography analysed in this research serves as a glimpse for the development of at least two different typologies of medical topographies in Europe in the $19^{\text {th }}$ and $20^{\text {th }}$ centuries. The first of them, carried out in urban contexts, converges in a new consideration of nature as a place of enjoyment, healing and tranquility, where the mountain appears as an ideal framework for the correct development of the enlightened society. Faced with these postulates, the medical topographies carried out in rural areas speak of other dynamics, aimed more at embedding a solid relationship between the possibilities of development in the countryside, the search for the improvement of living conditions and the health of the population and the remarkable relationship between the harsh circumstances and the numerous limitations on the use of the territory, with a situation of widespread poverty. 
This research shows a high degree of relationship with the context of the pandemic, currently caused by the global incidence of the COVID-19 virus. Although the diseases of the late $19^{\text {th }}$ century did not have the same characteristics as the virus that emerged in 2019, nor can the patterns of social behaviour be compared. The documents of the medical topographies show parallelism in the treatment of general pandemic situations. As today, the doctors who made the medical topographies appreciated the need to control climatic factors, movements of people and medical infrastructures to respond to unexpected and unpredictable healthcare situations.

In the analysed work, the main health problems treated have to do with tuberculosis and tertian fevers, which, as is the case today with COVID-19, were diseases for which medicine had not found an answer. Medical topographies already influence the need to confine the patients in places with the best care capacity (in the case of tuberculosis, sanitariums and hospitals were proposed throughout the European geography). Similarly, in situations of endemic and epidemic diseases of the $19^{\text {th }}$ and early $20^{\text {th }}$ centuries, population overcrowding was a problem, and widespread isolation was recommended, especially in continuous population centres.

Medical geographies, at least in the European context, have not been studied in the depth they deserve, nor has the enormous amount of data of all kinds they contain been sufficiently considered. Neither has the necessary attention been paid, according to the criteria of the research team, to the field of knowledge that created the hygienist trend linked to studies on the environment.

This study aims to highlight the formidable effort made by institutions such as the National Library or the Royal Academy of Medicine of Spain, the American Geographical Society or the Bibliothèque Nationale de France, among many others, to digitise and network a massive set of medical works of great interest to geography in particular and society in general. In moments of social and healthcare crises like the one we are experiencing at present, it is essential to know what was, in the history of humanity, the response that doctors, political actors and the general population gave to episodes of the massive spread of diseases. The investigative potential of these documents is, even today, little explored, but, without a doubt, the current ease of access to them will increase their use by researchers.

Medical Topographies, as technical documents that had the purpose of relating the physical characteristics of the place and the customs of its inhabitants, have a remarkable value in understanding symptoms and health aspects of relevance about the population. They also acquire a role of notable influence in the study of the change in mentality about the environment, which has not ceased to be a key aspect in shaping the fundaments on which Human Geography has been built in the last century. 


\section{References}

Aponte, E. (2006), "La geohistoria, un enfoque para el estudio del espacio venezolano desde una perspectiva interdisciplinaria, Scripta Nova, vol. 10, no. 218 (08), p. 112-135.

Arroyo Ilera, F. and Camarero Bullón, C. (2019) "Water for Madrid. The problems of water supply in a pre-industrial capital" in A. Rodrigues and A. Merlos (eds.) History of Water Management in the Iberian Peninsula between the Sixteenth and the Nineteenth Centuries: A comparative approach, Springer.

Atkins, P., Simmons, I. and Roberts, B. (1988), People, land and time: an historical intro-duction to the relations between landscape, culture and environment, Arnold, London, pp. 304.

Camarero Bullón, C. (2002), "Averiguarlo todo de todos: El catastro de Ensenada", Estudios Geográficos, vol. 63, bo. 248-249, p. 493-532.

Campos, R. (2008), "El desarrollo de la salud pública en España durante el siglo XX", Revista Eidon CSIC, vol. 13, p. 20-27.

Cárdenes, V., Ponce de León, M., Rodríguez, X.A. and Rubio-Ordoñez, A. (2019), "Roofing Slate Industry in Spain: History, Geology, and Geoheritage", Geoheritage, vol. 11, no. 1, p. 19-34.

Casco Solís, J. (2001), "Las topografías médicas: revisión y cronología", Asclepio, vol. LIII, no. 1, p. 213-244.

Chun, Y., Kwan, M.P. and Griffith, D.A. (2019), "Uncertainty and context in GIScience and geography: challenges in the era of geospatial big data", International Journal of Geographical Information Science, vol. 32, p. 12-24.

García Juan, L., Vallina Rodríguez, A. and Aguilar Cuesta, A.I. (2018), "¿Hacia una IDE para fuentes geohistóricas?", Mapping, vol. 191, no. 27, p. 38-48.

Henriques, M.H., dos Reis, R., Brilha, J. and Mota, T. (2011), "Geoconservation as an Emerging Geoscience", Geoheritage, vol. 3, no. 2, p. 117-128.

Hernández Briz, B.M. (1909), Geografía o topografía médica de la sierra del Guadarrama: Partido Municipal de San Lorenzo, Imprenta Helénica, Madrid.

Hernández Briz, B.M. (1919), Sanatorios de montaña para tuberculosos, El Siglo Médico de Madrid.

Huzui, A.E., Călin, I. and Pătru-Stupariu, I. (2012), "Spatial Pattern Analyses of Landscape using Multi-Temporal Data Sources", Procedia Environmental Sciences, vol. 14, p. 98-110.

Kearns, K.A. and Joseph, A.E. (1993), "Space in its place: Developing the link in medical geography", Social Science E Medicine, vol. 37, no. 6, p. 711-717.

Kwan, M.P. (2012), "The uncertain geographic context problem", Annals of the Association of American Geographers, vol. 102, no. 5, p. 958-968.

Labasse, J. (1982), La ciudad y el hospital: Geografia hospitalaria, Instituto de Estudios de Administración Local, Madrid, pp. 379.

Llanos, B. (1825), Memoria sobre los medios de mejorar el clima de Madrid, restablecer su salubridad y fertilidad, Editor Fuentenebro, Madrid.

López Piñero, J.M. (1992), "Las ciencias médicas en la España del siglo XIX", Ayer, vol. 7, p. 193-240. 
Meade, M.S. (2014), "Medical Geography", in W.C. Cockerham, R. Dingwall and S. Quah (eds) The Wiley Blackwell Encyclopedia of Health, Illness, Behavior, and Society, John Wiley \& Sons Ltd. Published.

Monna, F., Galop, D., Carozza, L., Tual, M., Beyrie, A., Marembert, F., Chateau, C., Dominik, J. and Grousset, F.E. (2004), "Environmental impact of early Basque mining and smelting recorded in a high minerogenic peat deposit", Science of the Total Environment, vol. 327, p. 194-214.

Ortega Cantero, N. (2019), "La visión moderna del paisaje en la geografía española", Boletín de la Real Sociedad Geográfica, vol. CLIII, p. 13-30.

Parr, H. (2004), "Medical geography: critical medical and health geography?" Progress in Human Geography, vol. 22, no. 2, p. 246-257.

Pèlachs Mañosa, A. (2006), "Algunes reflexions sobre geografia, paisatge i geohistòria ambiental", Documents d'Anàlisi Geogràfica, vol. 48, p. 179-192.

Taylor, K. and Rudwick, M. (2009), "The Establishment of Geohistory", Isis, vol. 100 , no. 4, p. 872-880.

Tomaszewski, B. (2008), "Producing Geo-historical Context from Implicit Sources: A Geovisual Analytics Approach", The Cartographic Journal, vol. 45, no. 3, p. 165-181.

Urteaga González, J.L., (1980), "Miseria, miasmas y microbios. Las topografías médicas y el estudio del medio ambiente en el siglo XIX", GeoCrítica, vol. 29, no. V, p. 1- 50 .

Vallina Rodríguez, A. (2017a), "Visual landscape: theoretical-methodological perspectives", Geocalli, vol. 36, no. 18.

Vallina Rodríguez, A. (2017b), "Perception of the landscape linked to the Sierra de Guadarrama National Park from the analysis of its visual properties", $X X V$ Congress AGE, p. 272-283, Spain. 